Environment Conservation Journal 15(1\&2) 161-169, 2014

ISSN 0972-3099 (Print) 2278-5124 (Online)

Abstracted and Indexed

\title{
Existing practices of rural women related to environmental sanitation
}

\author{
Poree Saikia Gogoi $\llbracket$, Juliana Sharma and Manju Dutta Das
}

Received:15.07.2013

Revised:05.09.2013

Accepted:21.10.2013

\begin{abstract}
The present investigation was undertaken to study the existing Practices of rural women related to environmental sanitation. The study was conducted in six villages under Jorhat Development Block of Jorhat District of Assam. A sample of 100 respondents were selected randomly with probability proportional sampling technique and the data were collected with the help of interview schedule. The study revealed that the existing practices of non-tribal women were highly satisfactory then tribal women.
\end{abstract}

Keywords: Environmental sanitation, rural women

\section{Introduction}

Health and environmental sanitation are the other essential needs of human being, which exist along with food, clothing and shelter. Knowledge regarding health and environmental sanitary practices is required for well being of an individual. In general environmental sanitation means a place where the residential quarters, cattle shed, the village lanes and streets were regularly swept and kept cleaned, free from open ditches, pools or slushes, dung heaps or garbage and faced matter fouling the whole surrounding and drainage facilities and arrangement for regular disposal of refuse (Setty, 1981). The environmental sanitation had a direct bearing on the health status of the people. Lack of proper environmental condition has been the major cause of many killer diseases in most countries of the world, including India.

In India most of the people live in villages where the sanitary conditions are very poor. As we know a country can not make sound progress unless its rural conditions are improved. Though after independence India has progressed a lot, yet spread of diseases and growth of harmful organism due to improper disposal of sewage and refuse, lack of drainage system, habit of open defecation by the villagers, lack of safe water, stagnated water pools, insanitary food supply etc. are common problems prevalent in the society, which contribute the poor quality of life. According to the Ministry of Health (1998) in India around 7,00,000 children die each

\section{Author's Address}

Deptt of Extension Education, College of Home Science, AAU, Jorhat,

Email: poreesaikia@gmail.com year due to diarrohoea and other water/ sanitation related diseases. Therefore environmental sanitation is one of the important area on which developing countries of the world are focusing attention to improve the living condition and health status of the people. And village sanitation can be improved only when people understand its importance that sanitation plays a pivotal role in the prevention of communicable diseases and also helps in improving the quality of life of people. As we know women had a greater role to play at home as well as its surrounding therefore keeping this in mind the present investigation was undertaken to identify the existing practices of rural women related to environmental sanitation.

\section{Material and Methods}

The present study was conducted in six villages (three non-tribal villages and three tribal villages) under Jorhat Development Block of Jorhat district of Assam. A sample of 100 respondents was selected randomly with probability proportional sampling technique. An interview schedule was prepared for data collection for analyzing the data statistical technique namely frequency and percentage is used.

Existing practices of rural women related to environmental sanitation

\section{Source of water}

Distribution of respondents having different sources of water is presented in Table 1 . The study shows that 38 per cent of total respondents had both pond and tap as their sources of water. 
Gogoi et al.

Table 1.Distribution of respondents having different sources of water

\begin{tabular}{|l|c|l|c|l|c|r|}
\hline Source of water & \multicolumn{2}{|c|}{$\begin{array}{c}\text { Non-tribal } \\
\text { (n=51) }\end{array}$} & \multicolumn{2}{c|}{ Tribal } & \multicolumn{2}{c|}{$\begin{array}{c}\text { Total } \\
(\mathbf{n}=100)\end{array}$} \\
\hline & $\mathrm{f}$ & $\%$ & $\mathrm{f}$ & $\%$ & $\mathrm{f}$ & $\%$ \\
\hline Only pond & - & - & 36 & 73.47 & 36 & 36 \\
\hline Pond and well & 6 & 11.76 & - & - & 6 & 6 \\
\hline Pond and tube well & 11 & 21.57 & 9 & 18.37 & 20 & 20 \\
\hline Pond and tap & 34 & 66.67 & 4 & 8.16 & 38 & 38 \\
\hline
\end{tabular}

A large majority (73.47 per cent) of tribal respondent had pond as an only source of water.

Similar findings were also reported by Sardana (1998) and Rajkhowa (1994) that source of water for majority of the respondents was pond water.

Distribution of respondents according to the adoption of some sanitary practices regarding source of water. Distribution of respondents of both tribal and non-tribal areas according to the adoption of some sanitary practices regarding source of water are shown in Table 2.

\section{Covering of well}

The data presented in Table 2 indicate that no respondents covered their well. This might be due to the fact that the respondents had no knowledge of preventing the well from entering outside dirty material.

Cleaning the surrounding area of source of water

A perusal of the Table 2 reveals that all the respondents cleaned the surrounding area of source of water regularly.

Keeping the sides of pond and well sufficiently high

The data in the Table 2 indicates that the sides of pond and well of a large majority of respondents (97 per cent) were sufficiently higher than the ground. This might be due to the fact that the respondents had knowledge of preventing the pond and well from entering outside dirty water.
Cleaning of pond or well regularly

Table 2 shows that a large majority of the respondents (87 per cent) cleaned their pond or well regularly.

Chemical used for cleaning the pond

A perusal of Table 2 reveals that the 61 per cent of the respondents used lime for cleaning the pond followed by 34 per cent used both alum and lime for cleaning the pond.

Use of separate clean utensil to take out water from the pond or well

The data in Table 2 indicates that a large majority of respondents (90 per cent) used separate clean utensil to take out water from the source of water i.e. pond or well.

Using same pond for drinking as well as for bathing and washing utensil and clothes.

Table 2 shows that majority (63 per cent) of respondents did not use the same pond for drinking as well as for taking bath and washing clothes and utensil.

Existence of fishery and use of water from Existence of fishery and use of water from

Distribution of respondents according to the existence of fishery and use of water from fishery for drinking are shown in Table 3. A perusal of Table 3 shows that majority of the respondents (61 per cent) had no fishery. More than 26 per cent of tribal women used water from their fishery for drinking. 
Table 2. Distribution of respondents according to the adoption of some sanitary practices regarding source of water

\begin{tabular}{|l|l|l|l|l|l|l|}
\hline \multicolumn{1}{|c|}{ Characteristics } & \multicolumn{2}{|c|}{$\begin{array}{c}\text { Non-tribal } \\
\text { (n=51) }\end{array}$} & \multicolumn{2}{c|}{$\begin{array}{c}\text { Tribal } \\
\text { (n=49) }\end{array}$} & \multicolumn{2}{c|}{$\begin{array}{c}\text { Total } \\
\text { (n=100) }\end{array}$} \\
\hline & $\mathrm{f}$ & $\%$ & $\mathrm{f}$ & $\%$ & $\mathrm{f}$ & $\%$ \\
\hline Covering of well & & & & & & \\
\hline Covered & - & - & - & - & - & - \\
\hline Not covered & 51 & 100.00 & 49 & 100.00 & 100 & 100 \\
\hline $\begin{array}{l}\text { Cleaning the surrounding area of } \\
\text { sources of water }\end{array}$ & & & & & & \\
\hline Yes & 51 & 100.00 & 49 & 100.00 & 100 & 100 \\
\hline No & - & - & - & - & - & - \\
\hline $\begin{array}{l}\text { Keeping the sides of pond and well } \\
\text { sufficiently high }\end{array}$ & & & & & & \\
\hline Yes & 50 & 98.03 & 47 & 95.91 & 97 & 97 \\
\hline No & 1 & 1.97 & 2 & 4.09 & 3 & 3 \\
\hline Cleaning of pond or well regularly & & & & & & \\
\hline Yes & 51 & 100 & 36 & 73.46 & 87 & 87 \\
\hline No & - & - & 13 & 26.54 & 13 & 13 \\
\hline Chemical used for cleaning the pond & & & & & & \\
\hline Alum & 3 & 5.88 & 2 & 4.08 & 5 & 5 \\
\hline Lime & 27 & 52.94 & 34 & 69.39 & 61 & 61 \\
\hline Alum and lime & 21 & 41.18 & 13 & 26.53 & 34 & 34 \\
\hline $\begin{array}{l}\text { Using separate clean utensil to take out } \\
\text { water from the pond or well }\end{array}$ & & & & & & \\
\hline Yes & 51 & 100 & 39 & 79.59 & 90 & 90 \\
\hline No & - & - & 10 & 20.49 & 10 & 10 \\
\hline $\begin{array}{l}\text { Using same pond for drinking, bathing, } \\
\text { washing, etc. }\end{array}$ & & & & & & \\
\hline Yes & 12 & 23.53 & 25 & 51.02 & 37 & 37 \\
\hline No & 39 & 76.47 & 24 & 48.98 & 63 & 63 \\
\hline
\end{tabular}

Table 3. Distribution of respondents according to the existence of fishery and use of water from existed fishery for drinking

\begin{tabular}{|l|l|l|l|l|l|l|}
\hline \multicolumn{1}{|c|}{ Fishery } & \multicolumn{2}{c|}{$\begin{array}{c}\text { Non-tribal } \\
\text { (n=51) }\end{array}$} & \multicolumn{2}{c|}{$\begin{array}{c}\text { Tribal } \\
(\mathbf{n = 4 9 )}\end{array}$} & \multicolumn{2}{c|}{$\begin{array}{c}\text { Total } \\
(\mathbf{n = 1 0 0})\end{array}$} \\
\hline & $\mathrm{f}$ & $\%$ & $\mathrm{f}$ & $\%$ & $\mathrm{f}$ & $\%$ \\
\hline Not existed & 34 & 66.70 & 27 & 55.20 & 61 & 61 \\
\hline $\begin{array}{l}\text { Fuse of water from existed } \\
\text { Fishery for drinking }\end{array}$ & & & & & & \\
\hline Used & 2 & 3.90 & 13 & 26.50 & 15 & 15 \\
\hline Not used & 15 & 29.40 & 9 & 18.30 & 24 & 24 \\
\hline
\end{tabular}


Gogoi et al.

Table 4. Distribution of respondents according to the use of area for washing utensils and clothes

\begin{tabular}{|c|c|c|c|c|c|c|}
\hline \multirow[t]{2}{*}{ Washing area } & \multicolumn{2}{|c|}{$\begin{array}{c}\text { Non-tribal } \\
(n=51)\end{array}$} & \multicolumn{2}{|c|}{$\begin{array}{l}\text { Tribal } \\
(n=49)\end{array}$} & \multicolumn{2}{|c|}{$\begin{array}{c}\text { Total } \\
(n=100)\end{array}$} \\
\hline & $\mathrm{f}$ & $\%$ & $\mathrm{f}$ & $\%$ & $\mathrm{f}$ & $\%$ \\
\hline \multicolumn{7}{|l|}{ For utensils } \\
\hline Inside the kitchen & - & - & - & - & - & - \\
\hline Outside the kitchen & 47 & 92.20 & 40 & 81.60 & 87 & 87 \\
\hline Near the pond & 4 & 7.80 & 9 & 18.40 & 13 & 13 \\
\hline \multicolumn{7}{|l|}{ For clothes } \\
\hline Inside the bathroom & 10 & 19.61 & 1 & 2.04 & 11 & 11 \\
\hline Separate area away from pond & 39 & 76.47 & 43 & 87.76 & 82 & 82 \\
\hline Very near to the pond & 2 & 3.92 & 5 & 10.20 & 7 & 7 \\
\hline
\end{tabular}

This might be due to the fact that the tribal utensil was present in their household.

respondents were not aware that fishery water is not Further analysis of the Table 4 indicates that 82 per suitable for drinking as it may cause differnent cent of the respondents washed clothes in a separate diseases.

\section{Washing area for utensil and clothes}

Distribution of respondents according to the use of area for washing utensils and clothes are shown in Table 4. Table 4 reveals that a large majority of the respondents (87 per cent) washed utensil outside the kitchen i.e., a separate arrangement for washing area away from pond. Similar findings was also reported by Saikia Baruah and Hazarika (1997) that majority of the respondents had separate arrangement for washing utensil and clothes.

\section{Bathing place}

Distribution of the respondents according to the use of area for bathing is shown in the Table 5 .

Table 5. Distribution of respondents according to the use of area for bathing

\begin{tabular}{|l|l|l|l|l|l|l|}
\hline \multicolumn{1}{|c|}{ Bathing area } & \multicolumn{2}{c|}{$\begin{array}{c}\text { Non-tribal } \\
\text { (n=51) }\end{array}$} & \multicolumn{2}{c|}{$\begin{array}{c}\text { Tribal } \\
(\mathbf{n = 4 9 )}\end{array}$} & \multicolumn{2}{c|}{$\begin{array}{c}\text { Total } \\
(\mathbf{n = 1 0 0})\end{array}$} \\
\hline & $\mathrm{f}$ & $\%$ & $\mathrm{f}$ & $\%$ & $\mathrm{f}$ & $\%$ \\
\hline Near the pond & 4 & 7.90 & 8 & 16.33 & 12 & 12 \\
\hline In the pond & - & - & 3 & 6.12 & 3 & 3 \\
\hline In the bathroom & 47 & 92.10 & 38 & 77.55 & 85 & 85 \\
\hline
\end{tabular}

Table 6. Distribution of respondents according to the way of disposing the household waste

\begin{tabular}{|l|l|l|l|l|l|l|}
\hline \multicolumn{1}{|c|}{ Household waste } & \multicolumn{2}{c|}{$\begin{array}{c}\text { Non-tribal } \\
\text { (n=51) }\end{array}$} & \multicolumn{2}{c|}{$\begin{array}{c}\text { Tribal } \\
(\mathbf{n = 4 9 )}\end{array}$} & \multicolumn{2}{c|}{$\begin{array}{c}\text { Total } \\
(\mathbf{n = 1 0 0}\end{array}$} \\
\hline & $\mathrm{f}$ & $\mathrm{y}$ & $\mathrm{f}$ & \multicolumn{1}{c|}{$\%$} & $\mathrm{f}$ & $\%$ \\
\hline Dumping in one place & 40 & 78.43 & 7 & 14.30 & 47 & 47 \\
\hline Throwing here and there & 8 & 15.60 & 42 & 85.70 & 50 & 50 \\
\hline $\begin{array}{l}\text { Gathering in a pit near the kitchen } \\
\text { garden }\end{array}$ & 3 & 5.80 & - & - & 3 & 3 \\
\hline
\end{tabular}

A perusal of Table 5 shows that a large majority of bathroom. It might be due to the fact that the respondents (85 per cent) took bath in the respondents had the knowledge of maintaining the 
hygiene as well the privacy. This finding is in line with Bora (1994) that majority of the respondents took bath in the bathroom.

\section{Disposal of household waste}

Distribution of respondents according to the way of disposing the household waste are presented in the Table 6. Table 6 shows that 50 per cent of the respondents threw household waste here and there creating a dirty surrounding. It is interesting to note that the percentage of throwing household waste here and there was higher in case of tribal respondents (85.7 per cent) than in non-tribal respondents (15.6 per cent). This might b e due to the fact that tribal respondents did not give more importance to keep the surrounding clean as a result they threw the household waste here and there. This study is inline with Adak (1990) and Sidhu et al. (1999) that majority of the respondents threw household waste here and there.

\section{Possessing drain and types of drain}

Distribution of respondents in possessing drainage system at their houses and types of drain are shown in the Table 7.

Table 7. Distribution of respondents in possessing drainage system and types of drain.

\begin{tabular}{|l|l|l|l|l|l|l|}
\hline \multicolumn{1}{|c|}{ Drainage system } & \multicolumn{2}{c|}{$\begin{array}{c}\text { Non-tribal } \\
\text { (n=51) }\end{array}$} & \multicolumn{2}{c|}{$\begin{array}{c}\text { Tribal } \\
(\mathbf{n = 4 9 )}\end{array}$} & \multicolumn{2}{c|}{$\begin{array}{c}\text { Total } \\
(\mathbf{n = 1 0 0})\end{array}$} \\
\hline & $\mathrm{f}$ & $\%$ & $\mathrm{f}$ & \multicolumn{1}{c|}{$\%$} & $\mathrm{f}$ & $\%$ \\
\hline Not existed & 9 & 17.65 & 47 & 95.90 & 56 & 56 \\
\hline Katcha drain & 40 & 78.43 & 2 & 4.10 & 42 & 42 \\
\hline Pucca drain & 2 & 3.92 & - & - & 2 & 2 \\
\hline
\end{tabular}

The data in Table 7 indicates that majority of the respondents (56 per cent) had no drainage system in their houses. Similar finding was reported by Aujula et al. (1988) that majority of the respondents had no drainage systems in their houses. It is also interesting to note that percentage of respondents of not possessing a drainage system was more in case of tribal respondents (95.90 per cent). The higher literacy rate of non-tribal respondents might have helped them to know about the importance and necessity of a drainage system; hence a high percentage of respondents (82.35 per cent) possessed drainage system in their household. Further analysis of the Table 7 indicate that 42 per cent respondents had katcha drain and a very negligible percentage of respondents had pucca drain.

Drainage facility to flow water of utensil washing area to kitchen garden

A large majority of respondents (95 per cent) had no drainage facility to flow the water from utensil washing area to kitchen garden. The respondents might have no knowledge that the stagnated water of utensil washing area could easily be drained to the kitchen garden for irrigating the garden and also could be kept the washing area clean.

\section{Defecation}

Distribution of respondents according to the use of place for defecation and the type of latrine is presented in the Table 8. A perusal of Table 8 reveals that only 26 per cent of the respondents used jungle for defecation which was higher in case of tribal respondents. The data in the table also shows that 45 per cent of the respondents had dug hole type of latrine and 29 per cent of the respondents had sanitary latrine. The percentage of possessing sanitary latrine was more in case of nontribal respondents. It is interesting to note that not a single household had low cost latrine. As the sanitary latrine costs more and the respondents might have no knowledge about the low cost latrine provided by the Government, therefore the maximum number of the respondents might have dug hole type of latrine. Similar findings was also reported by Saikia Baruah and Hazarika (1997) that a majority of the respodents had dug hole type of latrine. 


\section{Location of latrine and bathroom}

A large majority of the respondents (96 per cent) had latrine and bathroom not near to the sourceof water. The respondents might have knowledge about the fact that the water of latrine and bathroom could pollute the source of water.
This finding is in agreement with Bora (1994) that majority of the respondents had latrine, urinals and bathroom not near to the source of water.

Types of measures taken to get rid of mosquitoes Distribution of respondents according to the types of measures taken to get rid of mosquitoes are shown in the Table 9.

Table 8. Distribution of respondents according to the use of place for defecation and the type of latrine

\begin{tabular}{|c|c|c|c|c|c|c|}
\hline Defecation & \multicolumn{2}{|c|}{$\begin{array}{c}\text { Non-tribal } \\
\text { (n=51) }\end{array}$} & \multicolumn{2}{c|}{$\begin{array}{c}\text { Tribal } \\
(\mathbf{n = 4 9 )}\end{array}$} & \multicolumn{2}{c|}{$\begin{array}{c}\text { Total } \\
\text { (n=100) }\end{array}$} \\
\hline Open field & $\mathrm{f}$ & $\%$ & $\mathrm{f}$ & $\%$ & $\mathrm{f}$ & $\%$ \\
\hline Jungle & - & - & - & - & - & - \\
\hline Latrine & 7 & 13.70 & 19 & 38.80 & 26 & 26 \\
\hline Dug hole type of latrine & 19 & 37.30 & 26 & 53.00 & 45 & 45 \\
\hline Low cost latrine & - & - & - & - & - & - \\
\hline Sanitary latrine & 25 & 49.00 & 4 & 8.20 & 29 & 29 \\
\hline
\end{tabular}

Table 9. Distribution of respondents according to types of measures taken to get rid of mosquitoes

\begin{tabular}{|l|l|l|l|l|l|l|}
\hline & \multicolumn{2}{l|l|l|}{$\begin{array}{l}\text { Non-tribal } \\
\text { Measures }\end{array}$} & \multicolumn{1}{l|}{$\begin{array}{l}\text { Tribal } \\
(\mathbf{n = 4 9 )}\end{array}$} & \multicolumn{2}{l|}{$\begin{array}{l}\text { Total } \\
(\mathbf{n = 1 0 0 )}\end{array}$} \\
\hline & $\mathrm{f}$ & \% & $\mathrm{f}$ & $\%$ & $\mathrm{f}$ & $\%$ \\
\hline No measures & - & - & - & - & - & - \\
\hline Mosquito net* & 51 & 100.00 & 49 & 100.00 & 100 & 100 \\
\hline Mosquito coil* & 34 & 66.67 & 13 & 25.50 & 47 & 47 \\
\hline Cleaning the surrounding* & 50 & 98.03 & 48 & 97.90 & 98 & 98 \\
\hline Stopping the stagnated water* & 44 & 86.27 & 38 & 77.55 & 82 & 82 \\
\hline
\end{tabular}

* In addition to the other measure adopted

It is interesting to note that cent per cent of the respondents used mosquito net to get rid of mosquitoes. All the respondents might have the knowledge of the ill effect of mosquito bite. This findings is in agreement with Rajkhowa (1994) that cent per cent of the respondents used mosquitoes net to get rid of mosquitoes. Ninety eight per cent respondents cleaned the surrounding followed by 82 per cent who adopted the stopping of stagnated water and 47 per cent used mosquito coil as a measure to get rid of mosquitoes.

Type of measures taken to get rid of cockroach Distribution of respondents according to the types of measures taken to get rid of cockroach are shown in the Table 10.The data in Table 10 shows that majority 66 per cent of the respondents did not take any measure to get rid of cockroaches, followed by 30 per cent of the respondents used Shakti rekhka to get rid of cockroaches.

Type of measures taken to get rid of houseflies Distribution of respondents according to the types of measures taken to get rid of houseflies are shown in Table 11. A perusal of Table 11 shows that majority of the respondents (64 per cent) took measures to get rid of houseflies. Out of which 38 per cent used wire meshing followed by 26 per cent 
used phenyl to get rid of houseflies. It is interesting were unaware about the measures to be taken to note that less percentage of tribal respondents against houseflies and also they might have no took measures against houseflies. This might be knowledge that houseflies carry the germs of due to the fact that most of the tribal respondents diseases.

Table 10. Distribution of respondents according to the types of measures taken to get rid of cockroach

\begin{tabular}{|c|c|c|c|c|c|c|}
\hline \multirow[t]{2}{*}{ Measures } & \multicolumn{2}{|c|}{$\begin{array}{l}\text { Non-tribal } \\
(n=51)\end{array}$} & \multicolumn{2}{|c|}{$\begin{array}{l}\text { Tribal } \\
(n=49)\end{array}$} & \multicolumn{2}{|c|}{$\begin{array}{l}\text { Total } \\
(n=100)\end{array}$} \\
\hline & $\mathrm{f}$ & $\%$ & $\mathrm{f}$ & $\%$ & $\mathrm{f}$ & $\%$ \\
\hline No measures & 23 & 45.10 & 43 & 87.70 & 66 & 66 \\
\hline Finit & 4 & 7.80 & - & - & 4 & 4 \\
\hline Shakti rekha & 24 & 47.10 & 6 & 12.30 & 30 & 30 \\
\hline Other chemical & - & - & - & - & - & - \\
\hline
\end{tabular}

Table 11.Distribution of respondents according to the types of measures taken to get rid of houseflies

\begin{tabular}{|c|c|c|c|c|c|c|}
\hline \multirow[t]{2}{*}{ Measures } & \multicolumn{2}{|c|}{$\begin{array}{l}\text { Non-tribal } \\
(n=51)\end{array}$} & \multicolumn{2}{|c|}{$\begin{array}{l}\text { Tribal } \\
(n=49)\end{array}$} & \multicolumn{2}{|c|}{$\begin{array}{l}\text { Total } \\
(n=100)\end{array}$} \\
\hline & $\mathrm{f}$ & $\%$ & $\mathrm{f}$ & $\%$ & $\mathrm{f}$ & $\%$ \\
\hline No measures & 6 & 11.76 & 30 & 61.23 & 36 & 36 \\
\hline Wire meshing & 26 & 50.99 & 12 & 24.49 & 38 & 38 \\
\hline Phenyl & 19 & 37.25 & 7 & 14.28 & 26 & 26 \\
\hline Any other & - & - & - & - & - & - \\
\hline
\end{tabular}

\section{Type of chullah}

Distribution o respondents according to types of unaware about the importance of smokeless chullah chullah used by them are shown in Table 12. The and they might not have detailed knowledge about data in Table 12 includes that 39 per cent of the the smokeless chullah. This study is in line with respondents had both traditional chullah and gas Singh (1982) that most of the respondents had stove followed by 32 per cent respondents had only traditional chullah which were highly inefficient traditional chullah and none of the families had smokeless chullah which helps to economise the firewood and to make the kitchen smoke free.This might be due to the fact that the respondents were and hazardous to health.

\section{Types of cattle shed}

Distribution of respondents according to the types of cattle shed existed is shown in Table 13

Table 12.Distribution of respondents according to type of chullah used by them

\begin{tabular}{|l|l|l|l|l|l|l|}
\hline Chullah & \multicolumn{2}{l|}{ Non-tribal(n=51) } & \multicolumn{2}{l|}{ Tribal(n=49) } & \multicolumn{2}{l|}{ Total(n=100) } \\
\hline & $\mathrm{f}$ & $\mathrm{\%}$ & $\mathrm{f}$ & $\mathrm{\%}$ & $\mathrm{f}$ & $\%$ \\
\hline Traditional chullah & 9 & 17.65 & 23 & 46.94 & 32 & 32 \\
\hline $\begin{array}{l}\text { Traditional chullah and kerosene } \\
\text { stove }\end{array}$ & 5 & 9.80 & 15 & 30.61 & 20 & 20 \\
\hline Traditional chullah and gas stove & 28 & 54.90 & 11 & 22.45 & 39 & 39 \\
\hline $\begin{array}{l}\text { Traditional chullah, kerosene stove } \\
\text { and gas stove }\end{array}$ & 9 & 17.65 & - & - & 9 & 9 \\
\hline Smokeless chullah & - & - & - & - & - & - \\
\hline
\end{tabular}


Gogoi et al.

Table 13.Distribution of respondents according to the types of cattle shed existed

\begin{tabular}{|c|c|c|c|c|c|c|}
\hline \multirow[t]{2}{*}{ Cattle shed } & \multicolumn{2}{|c|}{$\begin{array}{l}\text { Non-tribal } \\
(n=51)\end{array}$} & \multicolumn{2}{|c|}{$\begin{array}{l}\text { Tribal } \\
(n=49)\end{array}$} & \multicolumn{2}{|c|}{$\begin{array}{l}\text { Total } \\
(n=100)\end{array}$} \\
\hline & $\mathrm{f}$ & $\%$ & $\mathrm{f}$ & $\%$ & $\mathrm{f}$ & $\%$ \\
\hline Not existed & - & - & - & - & - & - \\
\hline Pucca & - & - & - & - & - & - \\
\hline Katcha & 50 & 98.04 & 49 & 100.00 & 99 & 99 \\
\hline Semi-pucca & 1 & 1.96 & & - & 1 & 1 \\
\hline
\end{tabular}

Table 14.Distribution of respondents according to some information pertaining to cattle shed

\begin{tabular}{|c|c|c|c|c|c|c|}
\hline \multirow[t]{2}{*}{ Information of cattle shed } & \multicolumn{2}{|c|}{ Non-tribal $(n=51)$} & \multicolumn{2}{|c|}{ Tribal $(n=49)$} & \multicolumn{2}{|c|}{ Total(n=100) } \\
\hline & $f$ & $\%$ & $\mathrm{f}$ & $\%$ & $\mathrm{f}$ & $\%$ \\
\hline $\begin{array}{l}\text { Location } \\
\text { Away from the living house } \\
\text { Adjacent to the living house }\end{array}$ & 51 & 100 & 49 & 100 & 100 & 100 \\
\hline $\begin{array}{l}\text { Frequency of cleaning } \\
\text { Regularly } \\
\text { Sometimes } \\
\text { Rarely }\end{array}$ & $\begin{array}{l}51 \\
- \\
-\end{array}$ & $\begin{array}{l}100 \\
- \\
-\end{array}$ & $\begin{array}{l}49 \\
- \\
-\end{array}$ & $\begin{array}{l}100 \\
- \\
-\end{array}$ & $\begin{array}{r}100 \\
- \\
-\end{array}$ & $\begin{array}{l}100 \\
- \\
-\end{array}$ \\
\hline $\begin{array}{l}\text { Existence of drainage system } \\
\text { Existed } \\
\text { Non existed }\end{array}$ & 51 & $100^{-}$ & 49 & $100^{-}$ & $\begin{array}{r}- \\
100\end{array}$ & $\begin{array}{l}- \\
100\end{array}$ \\
\hline
\end{tabular}

A perusal of Table 13 shows that cent per cent respondents had cattle shed in their houses and most of their cattle shed were katcha (99 per cent). This findings is in agreement with Rajkhowa (1994) that majority of the respondents had katcha cattle shed.

Distribution of respondents according to some information pertaining to cattle shed

Distribution of respondents according to some information pertaining to cattle shed are shown in Table 14.

\section{Location of cattle shed}

The data in the Table 14 indicates that all the respondents had cattle shed away from the their living house. The respondents might have knowledge of hygiene which helped them to construct the cattle shed away from the living house. Similar findings was also reported by Bora (1994) that majority of the respondents had cattle shed away from the living house.

\section{Frequency of cleaning the cattle shed}

A perusal of the Table 14 reveals that all the respondents cleaned the cattle shed regularly.

Existence of drainage system in the cattle shed Table 14 shows that respondents did not have drainage system in the cattle shed. This might be due to the fact that the respondents were unaware of having a drainage system in the cattle shed to create a healthy environment.

\section{Conclusion}

From the study it can be concluded that majority of tribal respondents(73.47\%) had pond as their only source of water while majority of nontribal respondents (66.67\%) had both pond and tap as their source of water.Majority of non-tribal respondents (78.43\%) damped the household waste in one place whereas majority of tribal respondents (85.70\%) threw household waste here and there . Percentage of respondents having drainage system in their house were having drainage system in their house were found to be higher in case of non- tribal respondents $(82.35 \%)$ than in tribal respondents (4.10\%). Majority of respondents from tribal area (53.00\%) had only dug - hole type of latrine while 49 per cent of non- tribal respondents had sanitary latrine . Low - cost latrine was not found in any household. None of the families had smokeless chullah to economize the firewood and to create a smokefree environment. Thus the study revealed that the existing practices of non- tribal women were highly satisfactory then tribal women. 


\section{References}

Adak, D.K. 1990.Environmental sanitation and personal hygiene among the rural jaintias9Meghalaya). Journal of North East India.15(1):65-68

Aujla, P., Oberoi, K., Jindal, U. and Kaur, S. 1988. A study on sanitary and health status of rural households of Ludhiana district. Journal of Maharastra Agricultural University.13(1): 73-76.

Bora, M. M. 1994. A study on health habits and sanitary practices of housewives of cattle farmers in Kamrup district of Assam. Unpublished Ph. D. thesis, Assam Agricultural University, Jorhat.

Ministry of Health, 1998. In : Mitra, S.(1998) Rural sanitation in India- Issues and operations. Proceeding of the national seminar on rural sanitation. Rajiv Gandhi National Drinking Water Mission, New Delhi.

Rajkhowa, B. 1994. A study on environmental sanitation of rural households in Golaghat district, Assam.
Unpublished M.Sc (H.Sc) Thesis, Assam Agricultural University, Jorhat.

Saikia, Baruah, M. and Hazarika, D. 1997. Status of environmental sanitation of rural families of Jorhat district of Assam. Journal of Agriculture Science Society of North East India. 10(2):233-238

Sardana, S. 1988. A study of existing sanitary condition of rural households in Harayana. Harayana Agricultural University Journal of Research.18(2):153-155.

Setty, D.E. 1981. Rural sanitation need for a perspective plan. Social Welfare.XXXVIII:1-2.

Sidhu, M., Virk, M.K. and Singh, S. 1999. Effect of sanitation on health status of rural households. A study of Udaipur district of Rajasthan. Indian Journal of Ecology.20(1):90-93.

Singh, A. 1982. Evaluation of smokeless chullah. Rural India.12(2):10-12. 